\title{
First Trip Abroad: Expectations, Experiences and Stories of Transnational Romanians
}

\author{
Alin Croitoru1 2 * \\ ${ }^{1}$ University of Bucharest, Centre for Migration Studies - CeSMig, 9 Schitu Măgureanu, 010181 Bucharest, Romania \\ ${ }^{2}$ Lucian Blaga University of Sibiu, Centre for Social Research, 2-4 Lucian Blaga, 550169 Sibiu, Romania
}

KEYWORDS

International migration

Physical mobility

Transnationalism

Post-communism

Subjectivism

\begin{abstract}
The paper analyzes transnational Romanians' stories about their first trip abroad. The concept of physical mobility is seen in a broader framework for understanding transnational and cosmopolitan behaviours as well as international migration. In order to distinguish between different types of travelling for the first trip abroad the article is constructed keeping in mind the structural changes and constraints regarding physical mobility for Romanian citizens. During the process of transition from a communist country to the status of EU member, Romanian citizens' stories about travelling abroad for the first time fundamentally changed. Labour migrants, asylum seekers, business travellers, students or tourists left the countries with different expectations and faced different problems at destination. Their attitudes toward origin and destination framed their images about the first trip abroad. Using a qualitative approach and samples of Romanians who live in Denmark, Germany, Italy, Romania, Spain and the United Kingdom, the analysis emphasizes certain differences between different types of travelling for the first time abroad and reconstructs how Romanians started their transnational careers.
\end{abstract}

\section{Introduction}

The exploratory analysis of the first trip abroad is constructed on the hypothesis that structural changes and constraints in Romania influenced

\footnotetext{
* Contact address: alin.croitoru@ulbsibiu.ro (A. Croitoru)
} 
individual representations of countries they visited. The significant transformations which occurred in this country during the last decades create a fertile ground for this type of research because before 1989 the Romanian society was isolated and its borders were highly controlled, and now millions of Romanians live abroad. The short time in which this process has taken place and the variety of travel experiences allow us to differentiate between certain categories of people. The main dimensions that we keep in mind for this particular study are the historical period during which they left for their first time abroad, how much time they spent there and last but not least the reason for their trip. The main structural changes regarding Romanians' experiences of travelling abroad will be analysed between the years 1989 and 2007, and further broken down into three distinct periods of time. Two main events are taken into consideration as thresholds: firstly, there was the anti-communist revolution and its direct impact on the process of border liberalization; secondly, in 2007 Romania became part of the European Union and its citizens received the right to travel without restrictions within EU borders.

The selection of the first experience abroad was motivated by the fact that at this specific moment individuals naturally compare what they see with their own country. From this perspective, we can explore the idea that the subjective representations contain an important component rooted in the reality of where the visitor came from (Glick Schiller, Basch and BlancSzanton 2006 [1992], 8). To be more specific, individuals' expectations are based on the political, economic and social reality of Romania and this implies that in order to understand these stories one has to contextualize Romania during each of these three periods. For the time before 1989, the key concept of the first trip abroad is freedom even if the destination countries were also communist. The images of countries visited during the first few years after the Romanian revolution (1990-1995) seem to revolve around the concept of diversity, specifically of goods and services, as well as cultural diversity. After this period, Romanians' stories about crossing borders are more about the different ways in which work is rewarded. 
Historically, during this period from 1996 to 2006 Romanian flows of migration to Italy and Spain are strengthened and consolidated (Sandu 2010a). After Romanian integration into the EU a new set of motives for travelling arose. Work is still the main driver of migration, but leisure or educational trips are often mentioned as motivations for first trip abroad. This puzzle of time, destination and motives reconstructs the way in which Romanians started their transnational careers and gives us an insight into the individuals' framing process of travelling abroad during different periods.

The migration phenomenon has important implications in different aspects of the Romanians' life. A series of recent studies pointed out numerous effects on different dimensions of the Romanian society - through economic remittances (Dăianu, Voinea and Tolici 2001; Sandu 2012) or 'brain drain' (Reisz 2010) and social remittances with direct implications in changing social norms and values (Vlase 2013a, b) as well as demographical changes (Mihalache 2010; Avramescu 2009). The experience of living abroad influences people's orientation toward Europe and their opinions about the enlarging process of the EU (Roeder 2011). In the case of Romania, Sandu (2010b) emphasizes the importance of direct (former migrants) or indirect contact (in the case of migrant left-behinds) with other countries in changing Romanians' attitudes and behaviours. Our paper follows this line of thought and illustrates certain aspects concerning Romanians' first direct contacts with other countries and the impact of these experiences to their lives. There is a high probability that Romanians' transnational careers are quite similar to other Central or Eastern-Europeans stories. The shared communist background, the gradual access to western destinations and the significant segment of labour migrants in the total number of migrants constitute premises which allow for such comparisons. 


\section{Methodology}

Several EUCROSS ${ }^{1}$ working papers proposed 'cross-border practices' as the main concept for analysing physical and non-physical mobility (Favell et al. 2011; Hanquinet and Savage 2013; Salamońska, Baglioni and Recchi 2013). This concept is seen as a broader framework for understanding transnational and cosmopolitan behaviours as well as international migration. The conceptual tool proved to be useful in distinguishing between certain dimensions of daily and extraordinary practices:

'less permanent and more hybrid forms of border-crossing have been on the rise in the last decades: physical mobility such as transnational commuting, cross-border business and shopping, or split location lifestyles, and non-physical mobility such as the movement of money and savings, the consumption of international media, participation in virtual communities formed by people of different nationalities' (Favell et al. 2011, 24).

On this basis we should mention that our paper deals only with practices of physical mobility.

The EUCROSS project was based on mixed mode methodology and had two distinct research phases: firstly, a phone survey was conducted with representative samples for the native population in Denmark, Germany, Italy, Romania, Spain, and the United Kingdom; in addition there were two samples of Romanian and Turkish migrants, each sample consisted of 250 people; secondly, there was a qualitative approach focused on interviewing people with high level of transnationalism. This paper is based on fortyeight interviews conducted with Romanian citizens who live in previously mentioned European countries. From each of these samples, ten Romanian citizens were chosen on the basis of their answers to the phone survey ${ }^{2}$ in each of these countries and in the summer of 2013, they were interviewed

\footnotetext{
1 The Europeanisation of Everyday Life: Cross-Border Practices and Transnational Identities among EU and Third-Country Citizens. http://www.eucross.eu/cms/.

2 The level of transnationalism was measured on the basis on an index constructed in the EUCROSS Project and its main dimensions were linked to cross-border practices (physical and virtual mobility, cosmopolitan consumption and competencies) and transnational background and private network (Pötzschke 2012, 16).
} 
face-to-face ${ }^{3}$. The EUCROSS research design allowed for each of these samples to include eight people with high level of transnationalism and two with low level of transnationalism. Complementary, these respondents were selected, taking into account their gender and level of education (see Table 1 for the distribution of the sample). For this paper we selected only the interviews with people with a high level of transnationalism. Focusing the research on the transnational people, our perspective is not representative for the Romanian migration as a whole.

Table 1. Sample distribution by level of transnationalism, gender and level of education

\begin{tabular}{|c|c|c|c|c|c|c|c|c|}
\hline $\begin{array}{l}\text { Level of } \\
\text { trans- } \\
\text { nationalism }\end{array}$ & $\begin{array}{l}\text { Level of } \\
\text { education }\end{array}$ & Gender & Denmark & Germany & Italy & Romania & Spain & $\begin{array}{l}\text { United } \\
\text { Kingdom }\end{array}$ \\
\hline \multirow[t]{4}{*}{ High } & \multirow[t]{2}{*}{ High } & Women & 2 & 2 & 2 & 2 & 2 & 2 \\
\hline & & Men & 2 & 2 & 2 & 2 & 2 & 2 \\
\hline & \multirow[t]{2}{*}{ Low } & Women & 2 & 2 & 2 & 2 & 2 & 2 \\
\hline & & Men & 2 & 2 & 2 & 2 & 2 & 2 \\
\hline \multirow{2}{*}{\multicolumn{2}{|c|}{ Low }} & Women & 1 & 1 & 1 & 1 & 1 & 1 \\
\hline & & Men & 1 & 1 & 1 & 1 & 1 & 1 \\
\hline \multicolumn{2}{|l|}{ Total } & & 10 & 10 & 10 & 10 & 10 & 10 \\
\hline
\end{tabular}

There are certain limits generated by this type of methodological approach. Firstly, only a part of the sample accepted and provided a telephone number to be contacted for face-to-face interviews. Thus, selfselection influenced the content of the sample interviewed in the second phase of the project. Secondly, there were significant differences between Romanian immigrants depending on the country where they live. On the one hand, the field research in Germany and Denmark was conducted

\footnotetext{
3 The interviews were conducted by two different scholars of the University of Bucharest. The author of this paper conducted forty interviews in Denmark, Italy, Romania and the United Kingdom. The interviews in Germany and Spain were conducted by Monica Şerban. The geographical distribution of the sample includes Romanian citizens who live in: Denmark (Copenhagen, Aarhus, Aalborg and Glostrup), Germany (Munich, Cologne, Mannheim, Stuttgart and Murrhardt), Italy (Rome, Milano, Modena, Viareggio, Lecco, Vicenza, Padova and Lucca), Romania (Bucharest, Buzau, Călăraşi, Timişoara and Prahova), Spain (Madrid, Barcelona, Guadalajara, Toledo and Tarragona) and United Kingdom (London, Manchester, Romford and High Wycombe).
} 
smoothly (people accepted quite easily to settle face-to-face interviews and as a result the number of refusals was low). On the other hand, the interviews in Italy, Spain and the United Kingdom were more difficult to be conducted (in these countries the number of people who refused or cancelled the interview was considerable - for example, in Italy and the UK there were several cases when I scheduled the interview and the respondent never came at the meeting point and did not answer to the phone anymore). Even people who accepted the interview expressed their lack of trust in unknown Romanians who call them. As a consequence, there is a possibility that our respondents are quite different regarding their home orientation, transnational practices or attitudes towards Romania.

The interview focused on different dimensions of transnationalism and was structured in four main sections. Firstly, the discussion centred on the subject's experience of travelling abroad (a distinction was made between the first trip abroad and the most memorable trip). Secondly, questions were asked about the social circle and interaction with foreign citizens (this section was focused on international friendships, communication via the internet as well as on the subjects' opinions about the country where they live). The final part of the interview was concerned with the experiences of work, the economic crisis and EU issues. As we already mentioned, this paper only deals with the first part of the interview, but this first trip is seen in a broader context, a fact ensured by the interview's complementary topics. The empirical material constitutes the starting point for differentiating between distinct types of first trips abroad. These were constructed on the basis of the key element stressed by respondents in their stories as well as on objective criteria such as the historical period of the trip and the duration of time spent abroad. In order to emphasize the distinct elements of each type we use a series of quoted paragraphs for illustrating our classification. 


\section{Narrating the first trip abroad during different periods of time}

\section{A. The period of closed borders: first trip abroad before 1989}

Very few Romanians had the opportunity to go abroad during this historical period in which the communist regime had a very restrictive policy regarding travelling or communication. There were some destinations which were allowed for Romanians at that time, and many of them were other communist countries. These kinds of trips allow us to see people's expectations and can be used as a primary framework in which the countries visited are perceived. Additionally they create the opportunity to better understand the implications that the first trip abroad had for these people. It should be mentioned that going abroad was among the few chances for a Romanian to have direct contact with people from other countries and cultures, or in the words of one of our interviewees:

In the 1970s I don't think there were any foreigners; there wasn't even the notion of foreigners coming to Romania (...) It was a closed-off country that started to have a lot of problems when it came to... simple things that you need to survive. (Radu, 60, man, resident in Germany).

Radu is a Romanian citizen who left the country for good in the 1970s at the age of 17 with his parents. He had this opportunity only because his father was Jewish and they received the right to move to Israel. After a year spent in Israel they decided to move to Germany and he still lives there. This type of departure is interesting because in this case, a gap emerged between the individual and his native country:

You're already on the road. It doesn't matter! I mean, it's the same thing, I could've gone to a different country every two years (...). It is something you learn down the road. Because you don't have a country anymore, you have places where you say, OK, I was there and it was beautiful and I could go there again. But more than that no, you're not tied down, you're not connected to... (Radu, 60, man, resident in Germany).

This case of 'forced migration' cuts the individual's national roots and

\footnotetext{
4 All names used in this text are not the interviewees' real names. During the interview these persons were assured by their anonymity.
} 
transformed him into a cosmopolitan person. Certainly, this discourse about identity and belonging is different from the main narrative discourse of transnational Romanians. Asked how this dislocation occurred, Radu pointed out the importance of the first trip and he said that 'the first rupture is the hardest'. The period when this trip took place and the fact that it caused the total separation between the individual and Romania highlights new elements in the understanding of the first trip abroad and its consequences for the individual's identity.

Cristian is a Romanian migrant in Germany and his case is interesting for us because during the communist period he was allowed to go abroad. In the early 1970s along with ten colleagues he was sent to East Germany to work for about 14 months in a power station. A few years later, in 1988, this person was able to move abroad before the fall of communism. Asked about his feelings during his first trip he said:

Of course I was feeling extraordinary. I mean, this air I felt, I mean it doesn't have, what may I tell you? This soul and body freedom, I felt it of course then and when I went to Germany the second time. I don't feel it now. I tried to awake that feeling so many times, but I can't. So, there are only a few moments when you are inclined to feel some... special feelings. It's the same as with love; it doesn't come to everyone and anytime. There are unique moments, those two I felt then for the first time, when I arrived in Germany and I was there in... I felt like I was floating, I had the impression that it was a different air, another society, as if I wasn't standing on earth. (Cristian, 71, man, resident in Germany).

It is interesting to keep in mind the uniqueness associated with this first trip abroad during that time because as it was said, this feeling is directly linked to that of freedom. A similar example is provided by Marian, a Romanian citizen who has been living in Aarhus (Denmark) since 1988. His move from Romania to Denmark was his first trip abroad; his family had left for Denmark some time previously. One of the main differences experienced by Marian when he arrived in Denmark is described below:

The freedom was different. Everything was free, everything (...) During that time you didn't have the freedom to travel, to express yourself, there were a lot of things you couldn't find in Romania; many were forbidden. 
(Marian, 45, man, resident in Denmark).

These people construct their image on the background of the reality they left behind. The lack of freedom in Romania is seen in a new light when they have a point of comparison, and in this way crossing-borders provided a path to liberty and freedom.

Ana is a Romanian woman who now lives in London and who visited East Germany before 1989. She was part of a program organized by the communist authorities in the 1970s in which people who worked in the tourist industry were sent to Germany for about 5 months to acquire new skills. This trip was an opportunity for her to see differences between Romania and other countries. Her experience is an interesting example of a case in which direct contact with another country influences people to import social and cultural values into their own lives. Additionally, Ana is an example for the category of people encouraged to emigrate by their previous positive experiences. For example, she was amazed by the German way of behaving and she decided at that time that:

When I'll get married, I'll raise my children in the German way, and I did. And they emigrated; I didn't have to remind them ten times. I educated them since they were small, how to behave, what to do, to stay away from people that don't show a certain [way of behaving]... if they don't behave, move aside... (Ana, 55, woman, the United Kingdom).

Even if during the communist period Romania was isolated, there were few people who were able to go abroad and their stories allow us to identify some of the important starting points for a 'transnational career' analysis. On the one hand, we have cases of Romanians who left for good, mainly because they had opposing political views and many of these departures were directly or indirectly forced by the communist authorities. On the other hand, that historical period gave rise to certain opportunities of going abroad, namely trips organized by the communist authorities. This second type could be unpacked on the basis of stories briefly discussed above. These people saw in the 1970s that there are other possible ways of living and they noticed important economic, social, cultural and political differences between Romania and other countries. The distorted image 
intensively promoted by the communist authorities could be questioned and this was the result of going abroad and seeing other systems. This specific type of crossing borders during the communist period has some distinctive features. Firstly, these people were carefully selected by the authorities and their chances to go abroad were influenced by certain characteristics such as having a family who remained at home, having a 'clean political record' and being considered eligible by the Romanian Security Department. Secondly, an important role in organizing these trips abroad could be linked to the idea of group departures; this was significant because in this situation individuals knew that the system still had the power to supervise them. Other members of the group would be responsible for supervising the entire group and to prevent attempts to defect.

\section{B. The period of limited mobility (1990-2006)}

After the communist regimes collapsed a new period began for Romania: people were free to leave the country as they wished, however this did not mean complete freedom to travel as visa restrictions were imposed by most of the countries - this is why we are referring to this period of Romanian migration abroad in terms of limited mobility. New destinations and new motives began to spread and the first trip abroad receives a new meaning.

During the first few years of openness we should draw a clear distinction regarding practices of crossing-borders. Firstly there was consistent emigration of Romanian citizens with German and Hungarian ethnic origins towards these two countries (Sandu 2010a, 39). These flows of long term migration play an important role because some of the people who emigrated in the early 1990s provided information, opportunities and networks for Romanian temporary migrants (Sandu 2010a, 79). Secondly our interviews with transnational Romanians bring to the light a less explored category of first trip abroad, namely those travelling to Turkey. These trips to Turkey focus mainly on entrepreneurial opportunities. The process of economic reconfiguration of the Romanian market generated business incentives for people eager to go abroad (for trade). This 'Turkey boom' was 
possible because it was an accessible destination geographically and economically. Gradually, Romanians abandoned Turkey as a destination and they began to explore new destinations, mainly EU countries (Sandu et al. 2006; Sandu 2010a). Furthermore, travelling abroad evolved into more medium or long term fixed employment either within or outside of the regulated system, and this became the key element of their stories. In order to distinguish between the first trips abroad in this period of 'limited mobility' it is useful to take into account the duration, their expectations, experiences and images of these destinations.

In some ways, Turkey was a path to diversity and richness in terms of goods and services, and this destination represented an opened door to social diversity (in terms of social stratification) and cultural diversity (taking into account the differences regarding familial and religious values). In general, trips to Turkey had an entrepreneurial basis because in Romania at that time there was a scarcity of goods and many Romanians transformed suddenly into merchants and traders. The relationship between entrepreneurial orientation and travelling for the first time abroad generate a specific category of experiences. These individuals discovered opportunities on the goods market (Kirzner 1973, 1990) and for taking advantage of these they had to go abroad. From an economic perspective these people assume a status of 'arbitrageurs' (White 1990) because they link two markets, but their experience contains also an important socio-cultural component. It should be mentioned that Turkey is the main destination linked to entrepreneurial motives, but there are other destinations mentioned for this kind of first trip abroad such as Hungary, Poland and the Czech Republic. This type of entrepreneurs has a distinct profile compared to the transnational entrepreneurs analysed by Portes, Guarnizo and Haller (2002) mainly because the last category includes migrants who develop entrepreneurial behaviours in the destination context.

Mihnea lives close to Bucharest and he is one of the people who visited Turkey a few months after the Romanian revolution. He described his first short trip to Istanbul in these terms: 
Everything seemed fascinating - first of all, as far as I remember, I bought sweets. Then I remember buying a pair of trousers, each one of us bought blue jeans (...) In fact, you couldn't find sweets [in Romania]. You just couldn't. The only sweets were coming from this area, from Turkey. Those which you could find in Romania weren't that tasty. The Turks would wrap them very nice and colourful... We couldn't figure it out; we were impressed by colourful things. We were also fascinated by street lightning. We didn't know what all these things represented, but now we understand one has to be reserved when it comes to vivid colours and sugared flavours. (Mihnea, 56, man, resident in Romania).

Additionally, we can look at Flavius' story who describes this kind of trip in the terms of an adventure. He is a Romanian who lives in the Northern part of Italy and he recalls that he was surprised during his first trip to Turkey. To better understand the Romanian scarcity of goods in the early 1990s we can use his example of things that shocked him during this trip to Turkey. Firstly, there were little differences and small things which shocked him:

When I got to Turkey, the first time in my life, in Turkey... I remember I got off at the train station. The first time I went by train, not by car, in Turkey, and I saw Rexona soap at the spring that was for everyone. That was something that wouldn't have happened in Romania. And this thing... it also shocked me, but it also made me sad... (Flavius, 40, man, resident in Italy).

Secondly, he was amazed by their way of selling goods because:

(...) dozens of kilos of gold were in the window shops. The liberty they had. After communism, going to a kind of free country like Turkey... The liberty, the shops, these things were blinding you. The fact that you went to buy something, or you went to eat, they served you with coffee or tea, without paying for it. There were things we weren't used to. (Flavius, 40, man, resident in Italy).

The social and cultural differences between Romania and Turkey were discovered during these trips. Anca, a Romanian woman who is now dividing her life between Italy and Spain (she works a few months a year in Spain, but most of the time lives and works in Italy) recalls that during her first trip abroad to Turkey she saw a lot of differences: 
Their way of dressing and their way of behaving... In the 1990s there was still a time when women were more in the house. I understand that things have changed a lot now, in Turkey as well. You didn't really see them on the street dressed as us, as Europeans. Then their warm way of... The way they sell their products, they present their products, their hospitality things we weren't used to. Well, being the first time outside Romania's borders, it seemed something extraordinary. They weren't all dressed almost the same. (Anca, 45, woman, resident in Italy).

All these examples emphasize how illuminating the first trip abroad could be during the early 1990s, even if Turkey was not one of the richest countries of the world. The economic gap between countries was perceived by all these people and they returned to Romania aware of economic, social and cultural differences between Romania and other countries. Travelling to Turkey proved to be one of the most accessible paths for experiencing other countries during that period. The main elements that these trips had in common were their very short duration (measurable in days), their entrepreneurial motives, and probably one of the most notable consequence of these stories is linked to a deeper understanding of the idea of diversity.

During the same period of time another type of travelling for the first time abroad could be linked to people who left Romania seeking asylum. These stories are emotionally charged, which distinguishes them from other types of trips. People disappointed with Romania left illegally and tried to gain the right to stay for good in a new country. In some cases they have a settled destination or in other cases such as Gabriel's:

I did not know I will leave permanently, for the reason that we could not know for sure if we succeeded, but my intention was to leave and to settle somewhere, in another place than my own country. I was much too disappointed. (Gabriel, 51, man, resident in Denmark).

In this case more than in the others, crossing borders gets a new meaning because it involves a higher risk and a 'marginal status' in the destination country. Cristina is a Romanian who now lives in Germany but her experience of seeking asylum in Germany during the early 1990s was a negative one:

I'll remember for the rest of my life that moment because of the fear and 
horror. (Cristina, 44, woman, resident in Germany).

After she succeeded to get into Germany she tried to obtain the right to stay but one year later she was sent home by the police. After experiencing some terrible hardships during the journey from Romania to their destinations (in our cases, Germany and Denmark) these people had contact with a different world. Coming back to Gabriel's story, he pointed out that:

The endpoint was in Denmark. Today Denmark does not look that well, but then we were astonished at the German highways and roads and we were seeing how the car rolled, as if flying. When we got here, we thought that if Germany seemed a good place, than Denmark was perfect. (Gabriel, 51, man, resident in Denmark).

The negative feelings towards their native country, the danger of this trip and the welfare system encountered left an indelible imprint of these countries seen by Romanians at that specific time.

During this period of limited mobility, Romanians explored existing opportunities and collected information about different destinations (Sandu et al. 2006, 24). These changes were the result of the fact that more Romanians decided to take advantage of better labour opportunities located in other countries. As a consequence, the duration of these first trips abroad changed and therefore it is useful to distinguish between circular labour migrants and semi-permanent labour migrants. The first category includes people who left abroad for the first time usually for a period of three months and returned to Romania and they were engaged repeatedly in this type of labour migration. The second category is formed mainly by those people who left Romania around 2000 and who assumed an irregular status for years in the destination country (Italy and Spain became the main destinations).

Circular migration is a broad topic in migration studies and covers different types of repeated cross-border movements. Depending on the context encountered at destination, these types of circular labour migrants could become permanent migrants (Constan and Zimmermann 2011). In our paper, the destination is seen by Romanian migrants as a means of securing a better life and mainly as a possible path for improving the economic level 
of individuals or families (Potot 2010; Voicu 2005). This context creates situations in which people assume their temporary marginal status because they have a clear goal, namely to raise a certain amount of money and return home $^{5}$. Bogdana is a transnational Romanian woman who is now dividing her life between two countries - she lives and works two months in Austria and two months in Romania (in Austria she takes care of an older person in Graz, and in Romania she works in a Italian shoe factory). Her first trip abroad was in 2005 to Italy and in her case the economic nature of the trip is obvious:

(...) well, I would go to pay my debts, I had the bank, the mortgage, and you know it's very hard. (Bogdana, 43, woman, resident in Romania).

Her first trip abroad taught her simultaneously two lessons. Firstly, she found out how hard it is to work in the low paid job sector in another country, and secondly, she experienced the financial difference working abroad could make. The second lesson convinced her to become a circular migrant and to search the labour market for better opportunities; as a consequence, over time her destination changed from Italy to Austria. For a better understanding of Romanians' expectations of this specific type of trip we can take a short look at Cornelia's story. Cornelia was involved for a while in circular migration between Romania and Germany and now she lives in Germany.

Roxana is a Romanian woman who lives near London and who took her first trip abroad in 1995. She and her husband were part in a program which allowed Romanian students to work for a few months on farms in the UK. Talking about the differences between Romanians and British people she emphasizes that:

\footnotetext{
5 Rostas and Stoica (2007) illustrate the marginal status assumed by Romanian migrants. Some people tell about how they live under bridges or in improvised places for a while and others considered that working abroad as an irregular Romanian migrant makes you a slave. As a result, many people had a limited contact with the host society or in one of the immigrants' words: "My wife took care of an old woman. (...) I had no direct contact with the Italians, with their habits. I saw Italy from the blocks that we built and she through the window of the house" (Rostas and Stoica 2007, 344).
} 
The farmers who were simple farmers had such arrogance in them, superiority toward us who were his employees, some poor fellows. We were students from all the countries, especially from the poor ones. We were not only Romanians, but there were also Polish people, there were all kinds of people from the Eastern Europe countries. (Roxana, 41, woman, resident in the United Kingdom).

Roxana's case shows us the importance of money earned during these kinds of trips. After almost 20 years she remembers that:

We liked the freedom that money gives you. At that time when we were students, we could not afford to buy bananas. When we came to the UK, I bought bananas, put me to bed, I woke up at night, ate a banana and went back to sleep. So we liked that freedom that money gives you. (Roxana, 41, woman, resident in the United Kingdom).

Even if people accepted low paid jobs, they were able to experience the feeling of relative wealth (their social status improved at origin). These trips generated a mixture of emotions, the conflict between social frustration and economic satisfactions. Crossing-borders as a labour migrant for a limited period of time seems to have as main features the economic motivation for travelling abroad and the ambiguity felt by these people. In such cases the first trip abroad stimulated the desire for higher wages and also proved them that circular migration could be a way to acquire what they desired.

The final part of this section is concerned with Romanians who began their transnational careers as semi-permanent labour migrants. This label is used for delimitating a group of people who left Romania mainly around the year 2000 without a clear intention to come back. Their first trip abroad was linked to their desire to start a new life in a new country. Synchronically, during that period of time the irregular status of this type of migration tied them to the destination countries for years. Their expectations related to the destination country were different from the ones presented above and their experiences bring to light new images of how the first trip abroad took place. In this case we deal with 'people who live in and create a new social and cultural space which calls for a new awareness of who they are, a new consciousness, and new identities' (Glick Schiller, Basch and Blanc-Szanton 2006 [1992], 14). 
Rareş has been living in the UK since 2004. He points out from the beginning of his story that 'it was his dream to live abroad' and this fact distinguishes him from other people who were part of the program that allowed Romanians to work in farms from the UK:

We were split in half, the ones who came there to stay in this country, the ones who were just for the holiday, students, like I was, in my fourth year to top it off. I put my college on halt, I finished it in 2012, twelve years after I started it, in 2000, but half the students were there just to go back home. To earn some money, two months, money to support themselves through college. I didn't think like that, I wanted more, I felt that the college won't help me later in life. (Rareş, 33, man, resident in the United Kingdom).

A short look at Andrei's story adds valuable information about migrants' way of thinking. He left Romania in 2001 with a touristic visa to Germany, but his real destination was Spain 'it was a planned trip, with the intention to stay here, if things went well', and in his case the first trip abroad lasted 4 years and a half.

Alexandra has been living in Spain since 2001. She left the country at the age of 21, decided to settle down in a new country and the fact that she had some friends in the Madrid area influenced her to choose this destination. Talking about her first trip abroad, she confesses that:

I had illusions. I'm going to another country; I'm starting again no matter the consequences. (Alexandra, 34, woman, resident in Spain).

During the first months she succeeded in finding a job, a place to stay and began to overcome the language barriers and this was the moment when Spain received a new meaning for her:

(...) because I saw there was hope for the future. You have same rights and as woman you were respected, you had your rights as individual. (Alexandra, 34, woman, resident in Spain).

Alexandra's case is an example of a Romanian migrant decided to adapt to the new environment mostly because she perceived better life opportunities there in comparison with Romania. As we can see, these types of first trip abroad were animated by different individuals' expectations and as a result 
migrants were concerned from the beginning with finding a job and investing in acquiring useful knowledge about destinations (as Parutis (2014) shows, immigrants try to improve their working conditions from 'any job' to a 'better job' and after a while to a 'dream job'). Numerous interviewees point out the help received in the early stage at destination and we should emphasize that for the category of labour migrants the kinship networks played a significant role (Şerban and Grigoraş 2000; Anghel 2008; Şerban and Voicu 2010).

The first trip abroad as a semi-permanent migrant reconstructed from these stories emphasizes certain distinguishing elements. Firstly, in many cases, it is seen as a one-way trip because the first return to Romania took place after years. Secondly, these migrants were decided to settle down in a new country and to do the necessary things to remain there. Many of them already had relatives, friends or acquaintances at destinations and benefited from their help and 'it can be argued that border-crossing financing had a considerable impact on cutting the costs of labour migration, particularly in the immediate aftermath of the January 2002 visa waiver' (Ban 2009, 139). Expectations from the destination country were linked to the idea of a better life and the image of the first trip abroad is drawn in the lines of the adaptation/integration process.

Summarizing, the period of time between 1990 and 2006 is not unitary at all. Analysing this interval of time of limited mobility we distinguished between four main categories of people going abroad for the first time. The first one was constructed around the idea of entrepreneurial orientation. The second type allowed us to see how the first contact with another economic, social and cultural reality was seen by the asylum seekers. The third category was constructed on the basis of circular migration practices and the last one contains those people who left Romania with the desire to settle down in a new country for an undefined period of time. 


\section{The period of free intra-European mobility (after 2007)}

Since 2007 Romania has become a member state of the European Union and this represents the second crucial moment for understanding how Romanians' physical mobility developed through the last decades. The main feature of the period can be linked to the fact that the composition of migrant population is more diverse and there are no longer dominant characteristics we can speak of. Labour, educational and touristic motives are equally important for analysing the period of free intra-European mobility. The category of people who are likely to go abroad became larger to include many other kinds of migrants and motivations. Travelling abroad became easier and low-cost flights become popular solutions for going abroad (Favell et al. 2011). Labour migration flows were affected by the actual economic crisis and as a result Romanians were spurred to look at new destinations inside the EU and from this point of view our research brings to the light the importance of the UK and Denmark. Leisure activities and touristic trips as acts of 'mundane activities' (Pötzschke 2012, 18) are significantly increasing their weight in the total amount of departures. In order to distinguish between experiencing other countries after 2007, the paper focuses on people's expectations correlated with their motives for going abroad.

Educational trips have become an important practice that allowed young Romanians to experience other countries. From this point of view we can distinguish between those cases of going abroad for a short time during high-school or college and situations when people are enrolled in an educational system in another country - Denmark and the UK provide us some examples in this sense. There are significant differences between these two types of educational trips because one has different expectations depending on the time spent abroad.

Daniel is an eighteen year old man who lives in a Romanian city, and who left for a short educational trip in Spain in 2013. His school was part in an exchange students program. The week spent abroad in an international environment with teachers and students from eight countries fascinated 
him. Friendly people, Spanish cuisine and a relaxed urban look were the main memories from this trip. Such short experiences abroad seem to be an opportunity to directly experience one of the most pleasant faces of other countries. The social interaction eased by the school umbrella and the accommodation in another student house helped Daniel to develop some friendships and determined him to visit Spain next summer again. Another interesting example about the experience of going abroad through shorttime educational programs is offered by Valentin. At the interview time he was one of the Romanian students enrolled in the Denmark system and in high-school he spent a month in Germany together with a group of schoolmates. This trip was for him an incentive for going abroad for a longer period:

Let's say that it was the experience that made me believe that western European life is better than living in Romania. I saw that people were already stable here, I understood that. I saw that the young people who want to buy a particular chocolate just buy it. And I didn't have money. I think it was the first time I had some money because it was funded by the European Union and I got money every day so I can do my schoolwork, so I can buy a Coke, for example, during the job. (Valentin, 21, man, resident in Denmark).

This category of people is different from the others previously described because they receive a privileged treatment from the host schools, they see friendly faces, they do not worry about money or accommodation, and someone supports them during the entire visit. First time abroad as an exchange student in a short-time program has increased chances to be perceived as a very positive experience.

The second category of educational trips analysed includes people who left Romania for studying abroad and is concerned with medium and long term educational trips. This pattern of going abroad increased in popularity after the Romanian admission in the EU. Romanian students enrolled in universities from abroad perceived differently the first trip abroad mainly because they have different expectations compared with the other categories of people mentioned so far. Eduard is a Romanian who left 
Romania for studying at a University in Denmark. His case is interesting because it gives us a short insight in the early phase of adapting to a new country as a foreign student. Asked how he felt, he pointed out:

Interesting, everything was new. The first two months were pretty cool because everything was new and everything was discover, discover, discover... new experiences, new people. (Eduard, 23, man, resident in Denmark).

Additionally, his case gave us an insight into the relationship between natives and foreign students:

The first time I kept my distance from the Danish because they seemed pretty cold and I didn't really have anything in common with them. And the fact that I wasn't attracted to the language to learn it from the first year here; I didn't really have an interest. And if you don't speak Danish, you can't really fit into their groups. And how we were mostly foreigners, we didn't really have time for the Danish. We simply have our community of foreigners, all sorts of foreigners. We have our parties, our events... We don't really have moments when we interact with Danish people. (Eduard, 23, man, resident in Denmark).

He mentions that after a while he succeeded in building friendships with Danish people. The educational trip is a good means to acquire knowledge about other lifestyles and cultural patterns. However, Sigalas (2010) pointed out the limited nature of experiencing other countries during ERASMUS mobility.

Medium and long term educational trips differ from the short term trips because people have the opportunity to better understand the culture and the lifestyle in the destination country and also they experience the process of adaptation to a new reality. Similar results have been found in the case of Polish young people in the UK (Akhurst et al. 2014). Another important distinction between these is provided by the fact that usually short time educational trips during high-school time are organized in groups while medium and long term enrolment in another country is an individual process. Complementarily, students have access to a different social life in comparison with labour migrants or refugees and this aspect changes their perspective on the destination country. 
The last category of first trip abroad discussed in this paper can be linked to the 'tourist gaze' (Urry and Larsen 2011). Since 2007 going abroad for a vacation or a city-break has become a significant way to experience other countries for Romanians. These types of encounters are usually with people who are friendly in a commercialized fashion (Hochschild 2003). In numerous cases the combination between the little time spent at destination and a 'fake' image linked to the touristic area do not offer people a real contact with the destination country. Our sample of transnational Romanians with a large percent of Romanian migrants who live in other European countries allows us to see how a first touristic trip abroad could transform after a while in a decision to emigrate.

Raluca is a 26 years old Romanian woman who lives in Copenhagen and her first trip abroad was a touristic visit to Spain in 2007. Her uncle lived there for a while and she paid him a visit: 'it was just relaxing, having fun and I didn't work' - according to Faist, Fauser and Reisenauer $(2013,104)$ she already had been part of a transnational space because she was in touch with her uncle. In fact, the next year she took a new trip to Spain and that time she took a job for a couple of months. When her uncle decided to move from Spain to Denmark she decided to emigrate and asked him for a job. A different example is provided by Ruxandra. She lives in London and her first trip abroad was a touristic visit to Greece a few years ago. Her story offers us a new argument in this line. She mentions that she had a very pleasant time during this trip and adds that:

I was in Greece I thought to myself 'how would it be if I were to move to another country? I wonder how it would be.' (Ruxandra, 23, woman, resident in the United Kingdom).

These two examples show how a first touristic trip can transform into a starting point for a decision to emigrate and a transnational life. Positive experiences abroad give people direct access to information about other countries and can motivate them to go again abroad for longer periods.

To sum up, the Table 2 offers a brief description of the main types of the first trip abroad taking into account their characteristics and their 
consequences at the individual level. This typology is built on the basis of the empirical evidence presented in this paper and covers all the historical periods of time and categories of reasons presented above. Looking at the individual level, there is a series of consequences of these first trips abroad including reframing the individuals' cultural and political identities, increasing individuals' awareness about business or labour opportunities as well as stimulating their decision to emigrate.

Table 2. Characteristics of the main types of the first trip abroad

\begin{tabular}{|c|c|c|c|}
\hline & Motivation & Duration & $\begin{array}{l}\text { Some of the main consequences at the } \\
\text { individual level }\end{array}$ \\
\hline \multirow[t]{3}{*}{ Before 1989} & Political reasons & Long term & $\begin{array}{l}\text { Reframing individual's national identity (the } \\
\text { individuals' contacts with Romania were cut). }\end{array}$ \\
\hline & \multirow[b]{2}{*}{ Labour reasons } & \multirow{2}{*}{$\begin{array}{l}\text { Short and } \\
\text { medium } \\
\text { duration }\end{array}$} & $\begin{array}{l}\text { Increasing individuals' political awareness and } \\
\text { their critique attitude toward communism. }\end{array}$ \\
\hline & & & $\begin{array}{l}\text { Opening individual appetite for living abroad } \\
\text { when this thing became possible. }\end{array}$ \\
\hline \multirow{6}{*}{$\begin{array}{l}\text { The period } \\
\text { between } \\
1990 \text { and } \\
2006\end{array}$} & \multirow[b]{2}{*}{$\begin{array}{l}\text { Entrepreneurship } \\
\text { (small scale trade) }\end{array}$} & \multirow[b]{2}{*}{ Short term } & $\begin{array}{l}\text { Access to goods and services and stimulating } \\
\text { individuals' propensity to entrepreneurship. }\end{array}$ \\
\hline & & & $\begin{array}{l}\text { Increasing individual's capacity to search for } \\
\text { opportunities abroad (business and labour). }\end{array}$ \\
\hline & \multirow{3}{*}{ Labour reasons } & $\begin{array}{l}\text { Medium } \\
\text { duration }\end{array}$ & $\begin{array}{l}\text { Developing circular migration practices as part } \\
\text { of the individual/household economic strategy. }\end{array}$ \\
\hline & & \multirow[b]{2}{*}{ Long term } & $\begin{array}{l}\text { Separating individuals and their native country } \\
\text { for a significant period of time. }\end{array}$ \\
\hline & & & $\begin{array}{l}\text { Migrants had to make consistent efforts to adapt } \\
\text { to the destination context (their irregular status } \\
\text { left no other choice). }\end{array}$ \\
\hline & Asylum seeker & Long term & $\begin{array}{l}\text { The migrant operates with a clear distinction } \\
\text { between Romania (linked to a negative image) } \\
\text { and the host country (perceived in positive } \\
\text { terms). }\end{array}$ \\
\hline \multirow{6}{*}{ After 2007} & \multirow[t]{2}{*}{ Labour reasons } & \multirow{2}{*}{$\begin{array}{l}\text { Medium and } \\
\text { long term } \\
\text { trips }\end{array}$} & $\begin{array}{l}\text { Individuals' economic status improved and } \\
\text { their access to other cultures increased. }\end{array}$ \\
\hline & & & $\begin{array}{l}\text { Migrants could develop transnational lives } \\
\text { without restrictions (individuals can split their } \\
\text { lives between origin and destination). }\end{array}$ \\
\hline & \multirow[t]{2}{*}{ Educational reasons } & \multirow{2}{*}{$\begin{array}{l}\text { Short or } \\
\text { medium } \\
\text { duration }\end{array}$} & $\begin{array}{l}\text { Access to different information, educational } \\
\text { systems and scholarships programmes. }\end{array}$ \\
\hline & & & $\begin{array}{l}\text { Increasing individual abilities to be involved in } \\
\text { international networks and friendships. }\end{array}$ \\
\hline & \multirow[t]{2}{*}{ Tourism and leisure } & \multirow{2}{*}{$\begin{array}{l}\text { Short } \\
\text { duration }\end{array}$} & $\begin{array}{l}\text { Increasing individual level of knowledge about } \\
\text { other cultures and lifestyles. }\end{array}$ \\
\hline & & & $\begin{array}{l}\text { Physical mobility is often preceded by virtual } \\
\text { forms of mobility. }\end{array}$ \\
\hline
\end{tabular}




\section{Conclusions and discussion}

Romanians' stories about their first experiences abroad represent a useful starting point in analyzing how the perception on destinations fundamentally changed in only two decades. During different periods of time people who took their first trip abroad have had different expectations and framed their experiences in different terms. There are important transformations regarding people's knowledge about their destinations because in numerous cases people are already involved in transnational spaces. During the communist period and the early 1990s people who were abroad had limited knowledge about destinations. Starting with the second half of the 1990s and especially after 2007 Romanians who took their first trip abroad had already indirect knowledge about other countries through their relatives or friends who live there and through the internet massmedia, since the migration phenomenon became increasingly present in the public debate. In spite of the Romanian specific context described in this paper, we should mention that there is a high probability of similarities between Romania and other Eastern-European countries concerning the gradual evolution of this phenomenon.

Transnational Romanians' stories regarding their first trip abroad allowed us to differentiate between certain types of migrants (asylum seekers, circular migrants and semi-permanent migrants) and other kinds of travellers such us entrepreneurs, students and tourists. The first experience with another country took different forms during the last decades and each of them represents a key element for understanding people's expectations regarding their destinations. It does not mean that a person who took the first trip abroad during the communist period noticed only differences in terms of people's freedom; it is more about elements stressed in their stories. There are numerous examples of first trips abroad described as starting points for transnational careers and in many cases the individuals' orientation toward other cultures and their level of transnationalism are directly linked to these first direct contacts with other countries.

We presented two main categories of going for the first time abroad 
during the communist period, namely people who left for a definite period of time with the 'blessing' of the communist authorities and the category of people who left for an indefinite period of time and lost their contacts with Romania. A broader typology for this period of time should include other categories of people unrepresented in our sample, respectively the people who left Romania illegally and established in a new country (maybe this segment of people applied for citizenship in the destination countries and this is one of the reasons for not being in our sample); secondly there are people who left Romania during the communist time because they had different political opinions and this fact strengthened their Romanian identity (there is a chance for this kind of people to be out of our sample because they do not have a high level of transnationalism in the sense used in this paper, regardless of the long period of time spent abroad).

For the period of limited mobility between 1990 and 2006 we distinguished between four main categories of people. Firstly, we looked at asylum seekers and their stories about fears and motives to emigrate. Secondly, we pointed out the entrepreneurial orientation of a large category of people and how they experienced diversity through short time visits to Turkey. Thirdly, we unpacked the experience of going for the first time abroad as a labour migrant and from this perspective we drew a distinction between the ones who started their careers of circular migrants and the ones who assumed a status of irregular migrants and were linked to the destination country for a long period of time.

The free intra-European mobility that started in 2007 led to the intensification of certain ways of experiencing other countries for the first time such as the educational and the touristic trips. Even if labour migration continues to represent one of the significant drivers for travelling to another country for the first time, our sample of forty-eight transnational Romanians allowed us to see how these educational and touristic trips can motivate people to go abroad again for longer periods of time. Educational trips have an important imprint on individuals' process of defining their identities due to their early stage in life when they interact directly with a different culture. 
Romanians started their transnational careers in different fashions and this is an argument for the heterogeneity of the Romanian Diaspora. We found numerous reasons for going abroad during the specified periods of time. Our typology led to the selection of certain key elements for each of these periods of time without claiming to be an exhaustive exposition and the differences emphasized in the transnational Romanians' stories about their first trip abroad should not be seen in objective terms, but rather in subjective terms. Transnational Romanians pointed out different aspects during each historical period of time and the combination of duration, motives and destination allows a deeper understanding of the first trip abroad of transnational Romanians.

\section{Acknowledgments}

The author would like to express his gratitude to Dumitru Sandu, Monica Şerban, Elena Tudor and to Social Change Review peer reviewers for the valuable comments made on earlier drafts of this paper. Any remaining errors and omissions are, of course, entirely my responsibility.

The first draft of this paper was part of the working paper 'Romanians' social transnationalism in the making' co-authorized by Alin Croitoru, Dumitru Sandu and Elena Tudor, March 2014, EUCROSS FP7 - The Europeanisation of Everyday Life: Cross-Border Practices and Transnational Identities among EU and Third-Country Citizens http://www.eucross. $\mathrm{eu} / \mathrm{cms}$ /

\section{References}

Akhurst, Jacqui, Michal Janik, Margaret Szewczyk, Magdalena Mucha, Helen Westmancoat, Viv Lever, and Andreas Walmsley. 2014. "Polish Young Peoples' Narratives: Impacts of Living and Studying in the UK." International Migration 52 (1): 192-208.

Anghel, Remus Gabriel. 2008. "Changing statuses: Freedom of movement, locality and transnationality of irregular Romanian migrants in Milan." Journal of Ethnic and Migration Studies 34 (5): 787-802. 
Avramescu, Tiberiu. 2009. "The temporary migration from the rural environment abroad: socio-demographical profile and territorial characteristics." Studia Universitatis Babeş-Bolyai. Studia Europaea 54 (1): 73-87.

Ban, Cornel. 2009. "Economic Transnationalism and its Ambiguities: The Case of Romanian Migration to Italy." International Migration 50 (6): 129-149.

Constan, Amelie and Klaus Zimmermann. 2011. "Circular and Repeat Migration: Counts of Exits and Years Away from the Host Country." Population Research and Policy Review 30 (4): 495-515.

Dăianu, Daniel (coordinator), Liviu Voinea and Mugur Tolici. 2001. Balance of payments financing in Romania. The role of remittances. Romanian Center for Economic Policies.

Faist, Thomas, Margit Fauser, and Eveline Reisenauer. 2013. Transnational Migration. Cambridge: Polity Press.

Favell, Adrian, Ettore Recchi, Theresa Kuhn, Janne Solgaard Jensen, and Juliane Klein. 2011. "The Europeanisation of Everyday Life: CrossBorder Practices and Transnational Identifications Among EU and Third-Country Citizens." State of the Art Report no. EUCROSS Working Paper.

Glick Schiller, Nina, Linda Basch, and Cristina Blanc-Szanton. 2006 [1992]. "Transnationalism: A New Analytic Framework for Understanding Migration." Annals New York Academy of Sciences: 1-24.

Hanquinet, Laurie and Mike Savage. 2013. "Europeanisation and Globalisation." EUCROSS Working Paper.

Hochschild, Arlie Russell. 2003. The managed heart: commercialization of human feeling. London,: University of California Press Ltd.

Kirzner, Israel. 1973. Competition and Entrepreneurship. Chicago: University of Chicago Press.

Kirzner, Israel. 1990. "Uncertainty, Discovery, and Human Action: A Study of the Entrepreneurial Profile in the Misesian System." In Austrian Economics, edited by Stephen Littlechild, 122-143. Brookfield: Edward Elgar.

Mihalache, Flavius Florentin. 2010. "Schimbarea profilului demografic și ocupațional al populației rurale: 1990-2009." Calitatea Vieții (1-2): 2943.

Parutis, Violetta. 2014. "'Economic Migrants' or 'Middling Transnationals'? East European Migrants' Experiences of Work in the UK." International Migration 52 (1): 36-55. 
Portes, Alejandro, Luis Eduardo Guarnizo, and William J Haller. 2002. "Transnational entrepreneurs: An alternative form of immigrant economic adaptation." American Sociological Review 67 (2): 278-298.

Potot, Swanie. 2010. "Transitioning strategies of economic survival: Romanian migration during the transition process." In A Continent Moving West? EU Enlargement and Labour Migration from Central and Eastern Europe, edited by Richard Black, Godfried Engbersen, Marek Okolski and Cristina Pantîru, 249-271. Amsterdam: IMISCOE Research, Amsterdam University Press.

Pötzschke, Steffen. 2012. "Measuring Transnational Behaviours and Identities." EUCROSS Working Paper \# 4.

Reisz, Robert D. 2010. "Optimism and Migration in Romanian Academia." Journal of Social Research \& Policy 1 (1): 91-97.

Roeder, Antje. 2011. "Does Mobility Matter for Attitudes to Europe? A Multilevel Analysis of Immigrants' Attitudes to European Unification." Political Studies 59 (2): 458-471.

Rostas, Zoltan, and Sorin Stoica. 2006. Tur-Retur. Convorbiri despre munca în străinătate (vol. I). Edited by Doina Jela, Actual. Bucureşti: Editura Curtea Veche.

Salamońska, Justyna, Lorenzo Grifone Baglioni, and Ettore Recchi. 2013. "Navigating the European Space: Physical and Virtual Forms of Cross-Border Mobility among EU Citizens." EUCROSS Working Paper.

Sandu, Dumiru. 2010a. Lumile sociale ale migrației româneşti în străinătate. Iaşi: Polirom.

Sandu, Dumitru. 2010b. "Modernising Romanian society through temporary work abroad." In A Continent Moving West? EU enlargement and labour migration, edited by Richard Black, Godfried Engbersen, Marek Okolski and Cristina Panțîru, 271-289. Amsterdam: IMISCOE Research, Amsterdam University Press.

Sandu, Dumitru. 2012. (Re)embedding remittances into the lifeworlds of immigrants: contrasting social types. Bratislava: Central European Labour Studies Institute (CELSI).

Sandu, Dumitru, Ana Bleahu, Vlad Grigoraş, Alexandra Mihai, Cosmin Radu, Cerasela Radu, Monica Şerban, Alexandru Toth, Georgiana Toth, Simina Guga, Monica Jeler, Georgiana Păun, Mihaela Ştefănescu, and Delia Bobîrsc. 2006. Living Abroad on a Temporary Basis. The Economic Migration of Romanians: 1990-2006. Bucharest: Open Society Foundation. 
Şerban, Monica and Vlad Grigoraş. 2000. "Dogenii din Teleorman în țară și în străinătate. Un studiu asupra migrației circulatorii în Spania." Sociologie Românească (2): 30-54.

Şerban, Monica and Bogdan Voicu. 2010. "Romanian migrants to Spain: in or outside the migration networks a matter of time?" Revue d'etudes comparatives Est-Ouest 41 (1): 97-124.

Sigalas, Emmanuel. 2010. "Cross-border mobility and European identity: The effectiveness of intergroup contact during the ERASMUS year abroad." European Union Politics 11 (2): 241-265.

Urry, John and Jonas Larsen. 2011. The Tourist Gaze 3.0. London: Sage Publications Ltd.

Vlase, Ionela. 2013a. "'My Husband Is a Patriot': Gender and Romanian Family Return Migration from Italy." Journal of Ethnic and Migration Studies 39 (5): 741-758.

Vlase, Ionela. 2013b. "Women's social remittances and their implications at household level: A case study of Romanian migration to Italy." Migration Letters no. 10 (1): 81-90.

Voicu, Bogdan. 2005. Penuria Pseudo-Modernă a Postcomunismului Românesc.Vol. I. Schimbarea socială şi acțiunile indivizilor. Iaşi: Expert Projects.

White, Lawrence H. 1990. "Entrepreneurship, Imagination and the Question of Equilibration." In Austrian Economics, edited by Stephen Littlechild, 87-105. Brookfield: Edward Elgar. 